Published in "Botanical Journal of the Linnean Society 192(4): 656-674, 2020"

which should be cited to refer to this work.

\title{
Systematics of Vriesea (Bromeliaceae): phylogenetic relationships based on nuclear gene and partial plastome sequences
}

\author{
TALITA MOTA MACHADO ${ }^{1 *, \oplus,}$ ORIANE LOISEAU ${ }^{2}$, MARGOT PARIS $^{3}$, ANNA WEIGAND $^{4}$, \\ LEONARDO M. VERSIEUX ${ }^{5}$, JOÃO RENATO STEHMANN ${ }^{1}$, CHRISTIAN LEXER ${ }^{6}$ and \\ NICOLAS SALAMIN ${ }^{2, \bullet}$
}

${ }^{1}$ Departamento de Botânica, Instituto de Ciências Biológicas, Programa de Pós-Graduação em Biologia Vegetal, Universidade Federal de Minas Gerais, Belo Horizonte, CEP 31270-901, MG, Brazil

${ }^{2}$ Department of Computational Biology, University of Lausanne, 1015 Lausanne, Switzerland ${ }^{3}$ Department of Biology, Unit Ecology and Evolution, University of Fribourg, Fribourg, Switzerland ${ }^{4}$ Department of Systematic and Evolutionary Botany, University of Zurich, 8008, Zurich, Switzerland

${ }^{5}$ Laboratório de Botânica Sistemática, Departamento de Botânica e Zoologia, Centro de Biociências, Universidade Federal do Rio Grande do Norte, Natal, CEP 59078-970, RN, Brazil

${ }^{6}$ Department of Botany and Biodiversity Research, Faculty of Life Sciences, University of Vienna, Rennweg 14, 1030 Vienna, Austria

\begin{abstract}
Vriesea is the second largest genus in Tillandsioideae, the most diverse subfamily of Bromeliaceae. Although recent studies focusing on Tillandsioideae have improved the systematics of Vriesea, no consensus has been reached regarding the circumscription of the genus. Here, we present a phylogenetic analysis of core Tillandsioideae using the nuclear gene $p h y C$ and plastid data obtained from genome skimming. We investigate evolutionary relationships at the intergeneric level in Vrieseeae and at the intrageneric level in Vriesea s.s. We sampled a comprehensive dataset, including 11 genera of Tillandsioideae and nearly 50\% of all known Vriesea spp. Using a genome skimming approach, we obtained a 78 483-bp plastome alignment containing 35 complete and 55 partial protein-coding genes. Phylogenetic trees were reconstructed using maximum-likelihood based on three datasets: (1) the 78483 bp plastome alignment; (2) the nuclear gene $p h y C$ and (3) a concatenated alignment of 18 subselected plastid genes $+p h y C$. Additionally, a Bayesian inference was performed on the second and third datasets. These analyses revealed that Vriesea s.s. forms a well-supported clade encompassing most of the species of the genus. However, our results also identified several remaining issues in the systematics of Vriesea, including a few species nested in Tillandsia and Stigmatodon. Finally, we recognize some putative groups within Vriesea s.s., which we discuss in the light of their morphological and ecological characteristics.
\end{abstract}

ADDITIONAL KEYWORDS: Atlantic Forest - chloroplast - epiphytes - genome skimming - monocotyledons Neotropics - next-generation sequencing - Tillandsioideae.

\section{INTRODUCTION}

Bromeliaceae are a large, nearly entirely Neotropical plant family with a wide geographical distribution ranging from the southern United States to northern Patagonia in Argentina; a single species occurs in Africa (Smith \& Downs, 1974). Diversification in the

*Corresponding author. E-mail: machado.mota.t@gmail.com family has been suggested to be the result of rapid speciation and adaptive radiations mainly triggered by the evolution of key innovations that enabled species to colonize new adaptive zones (Givnish et al., 2011, 2014; Silvestro, Zizka \& Schulte, 2014). Morphological features, such as tank-forming leaves, epiphytism, water- and nutrient-absorbing leaf trichomes and CAM photosynthesis, have allowed bromeliads to colonize highly heterogeneous environments (Benzing, 
2000; Silvestro et al., 2014). Consequently, bromeliads occur from mesophytic forests to xerophytic rock outcrops, from sea level (e.g. restingas in Atlantic Forest) to the top of mountains in the Andes and the Brazilian Shield (Gilmartin, 1973; Krömer, Kessler \& Herzog, 2006; BFG, 2015, 2018). The wide variation in morphological characters and the low rates of molecular evolution observed in Bromeliaceae (Smith \& Donoghue, 2008; Maia et al., 2012) make this family of c. 3587 species in 75 genera (Butcher \& Gouda, cont. updated) a challenging group for taxonomists. Because of these characteristics, the delimitation of species, or sometimes even genera, has proved difficult (PalmaSilva et al., 2016).

Based on molecular phylogenetic analyses, eight subfamilies of Bromeliaceae, the circumscription of which was usually based on only a few plastid markers, are currently recognized in the literature (Terry, Brown \& Olmstead, 1997a, b; Horres et al., 2000; Crayn, Winter \& Smith, 2004; Barfuss et al., 2005; Givnish et al., 2007). In the last decades, many phylogenetic studies have improved our understanding of the evolutionary history of these subfamilies, but species representation has been highly heterogeneous among studies (Escobedo-Sarti et al., 2013; Palma-Silva et al., 2016). For instance, among the subfamilies with the highest number of published phylogenetic studies (Bromelioideae and Tillandsioideae), Tillandsioideae are also the subfamily with the most scattered and least connected sampling because most publications analysed only small clades (Escobedo-Sarti et al., 2013). As a result of the low rates of substitution in plastid regions, the tree topologies are often poorly resolved not helping in the circumscription of some genera in Bromeliaceae (Smith \& Donoghue, 2008; Maia et al., 2012; Palma-Silva et al., 2016); non-natural genera are frequently reported in Bromeliaceae (Barfuss et al., 2005; Evans et al., 2015; Schütz et al., 2016; Maciel et al., 2018) and only $30 \%$ of the currently recognized genera are monophyletic (Escobedo-Sarti et al., 2013). To overcome these problems, recent studies have increased the amount of analysed data either by increasing the number of molecular markers and their phylogenetic informativeness (e.g. more quickly evolving nuclear regions or even AFLP) or increasing the numbers of terminals (Krapp et al., 2014; Heller et al., 2015; Barfuss et al., 2016; Pinangé et al., 2016; Schütz et al., 2016; Goetze et al., 2017; Gomes-da-Silva \& Souza-Chies, 2017; Leme et al., 2017; Maciel et al., 2018; Matuszak-Renger et al., 2018). Nevertheless, large and complex to delimit genera such as Tillandsia L. (741 species), Pitcairnia L'Heritier (408 species), Vriesea Lindl. (226 species), Puya Molina (226 species) and Guzmania Ruiz \& Pav. (218 species) remain vastly under-sampled (Gouda,
Butcher \& Gouda, cont. updated; Palma-Silva et al., 2016; Schütz et al., 2016).

Vriesea, the fourth largest genus in Bromeliaceae (Gouda et al., cont. updated), highlights well the problems faced by current phylogenetic studies. In the genus, $88 \%$ of the species in the genus occur in Brazil, and $84 \%$ of all Vriesea spp. are endemic to the country (BFG, 2015, 2018). They are distributed from xeric to mesic environments (Versieux \& Wendt, 2007; Versieux, 2008; Costa, Gomes-da-Silva \& Wanderley, 2014; Machado, Forzza \& Stehmann, 2016) and are a conspicuous element of the Atlantic Forest (Martinelli et al., 2008). Some species reach a western inland distribution, growing as epiphytic, terrestrial or rupicolous plants on inselbergs and in rocky savannalike habitats (Versieux \& Wendt, 2007; Versieux et al., 2008; Costa et al., 2014). The geographical distribution of species varies from wide ranges covering different habitats to microendemics that are particularly frequent in mountainous environments (Versieux \& Wendt, 2007; Costa et al., 2014; Machado, Forzza \& Stehmann, 2016). Due to the restricted distributions of many Vriesea spp. and the continuous loss of habitat, the genus is the second most endangered in Brazil when considering the absolute number of endangered plant species (Martinelli et al., 2013). The wide climatic tolerance of Vriesea is coupled with morphological variation (Costa et al., 2014; Costa, Gomes-da-Silva \& Wanderley, 2015). Phenotypic variability occurs also at the intraspecific level, making the delimitation of taxa complicated, and leading to the recognition of several species complexes (Almeida et al., 2009; Gomes-daSilva \& Costa, 2011; Versieux, 2011; Neves et al., 2018).

The polyphyletic condition of Vriesea and the difficulty in recognizing unique morphological characters to circumscribe the genus have been known for over two decades (Terry et al., 1997a; Barfuss et al., 2005; Givnish et al., 2011; Gomes-da-Silva et al., 2012; Costa et al., 2015; Gomes-da-Silva \& SouzaChies, 2017). Recent studies using morphological characters and molecular markers have elucidated the intergeneric relations in Tillandsioideae and helped to improve the circumscription of Vriesea (Barfuss et al., 2016; Gomes-da-Silva \& Souza-Chies, 2017). However, conflicting results are found in the literature, potentially due to the low species sampling of Vriesea, which remains poorly representative of the whole genus. To achieve a robust classification, the last taxonomic revision of Tillandsioideae proposed a series of rearrangements dividing large polyphyletic genera into small, monophyletic, well-circumscribed morphological groups (Barfuss et al., 2016). Based on the stigma morphology, Vriesea s.l. was split into five new genera (Goudaea W.Till \& Barfuss, Jagrantia Barfuss \& W.Till, Lutheria Barfuss \& W.Till, Zizkaea 
W.Till \& Barfuss, Stigmatodon Leme, G.K.Br. \& Barfuss) and Vriesea s.s. (the Brazilian lineage) was recognized as monophyletic. Finally, Cipuropsis Ule was resurrected to accommodate the mesomorphic northern Andean 'Vriesea' spp. (Barfuss et al., 2016). However, the phylogenetic analysis conducted by Gomes-da-Silva \& Souza-Chies (2017) based on a total evidence approach (morphological data and four plastid markers) did not support the rearrangement of Vriesea s.l. proposed by Barfuss et al. (2016). Instead, Gomes-da-Silva \& Souza-Chies (2017) recognized only two lineages: (1) Vriesea s.s. encompassing all Brazilian species including Stigmatodon, a new genus described by Barfuss et al. (2016); and (2) Vriesea clade ß composed partly by the Cipuropsis-Mezobromelia L.B.Sm. complex and by Josemania, Goudaea, Lutheria and Jagrantia, new genera described in Barfuss et al. (2016). Thus, a consensus on genus delimitation in Vrieseeae, particularly in Vriesea s.l., has not yet been reached, calling for additional systematics studies of this group.

Here, we use the opportunity offered by nextgeneration sequencing to produce a plastid dataset obtained using the genome skimming approach. We combined this plastid dataset with sequences from the nuclear gene $p h y C$ to reconstruct the phylogenetic tree of core Tillandsioideae. We test the monophyly of the genera in Vrieseeae, investigate phylogenetic relationships at the intergeneric level and within Vriesea s.s. and discuss the efficiency of genome skimming for shallow-level phylogenetic reconstruction in bromeliads.

\section{MATERIAL AND METHODS}

\section{TAXON SAMPLING}

Our dataset included 206 specimens (148 species) for plastid data and 171 specimens (134 species) for nuclear data, totalling 227 specimens representing 151 species and three infraspecific taxa from 11 genera of Tillandsioideae. Of these, 110 species belonged to Vriesea s.l., representing $49 \%$ of the total number of described species according to Gouda et al. (cont. updated). Besides Vriesea, the number of species sampled in this study and the number of species per genus according to Gouda et al. (cont. updated) were as follows: Alcantarea (E.Morren ex Mez) Harms (11/42), Goudaea (2/2), Guzmania (4/218), Lutheria (2/4), Mezobromelia (1/5), Racinaea M.A.Spencer \& L.B.Sm. (1/78), Stigmatodon (5/18), Tillandsia (8/741), Werauhia J.R.Grant (3/93) and Zizkaea (1/1) (Supporting Information, Table S1).

Most samples were collected during fieldwork in Brazil. We tried to cover the greatest possible morphological and geographical variation of the species and type localities. To make the sampling as complete as possible, we also included specimens from the living collections of the Marie Selby Botanical Garden (SEL, United States), the Botanical Garden of the University of Vienna (WU-HBV, Austria), the Rio de Janeiro Botanical Garden (RBvb, Brazil) and the Jardin des Serres d'Auteuil (P, France). Details of the studied species and accession numbers are given in the Supporting Information (Table S1).

Ananas comosus (L.) Merr. was included as an outgroup for the different analyses. For the $p h y C$ nuclear gene, sequences from additional six species (including Ananas) where obtained from GenBank: Ananas comosus (NCBI number KU095956.1), Guzmania wittmackii (André) André ex Mez (NCBI number KX753898.1), Lutheria splendens (Brongn.) Barfuss \& W.Till (NCBI number KX753915.1), Tillandsia heubergeri Ehlers (NCBI number KX753920), Tillandsia stricta Sol. KX753950.1) and Tillandsia tenuifolia L. (NCBI number KX753909.1). For the genome skimming, raw reads from a whole genome sequencing of Ananas comosus 'N67-10' (NCBI number DRX020985) were added to the analyses together with the reads obtained in this study.

\section{DNA EXTRACTION}

Total genomic DNA was isolated from silicagel-dried leaves collected in the field or taken from living collections using the Quiagen DNAeasy Plant Mini Kit (Qiagen, USA). We adjusted the manufacturer's protocol to optimize the DNA extraction from the thick and fibrous leaves of bromeliads (contact authors for more details). Total DNA samples were evaluated with agarose gels and a NanoDrop Spectrophotometer (Thermo Scientific, Waltham, MA, USA). The DNA content was quantified with a Qubit Fluorometer v.2.2 (Thermo Fisher Scientific, Waltham, MA, USA).

\section{NUCLEAR PHYC GENE AMPLIFICATION, ASSEMBLY AND ALIGNMENT}

The nuclear $p h y C$ region amplification was based on primers and protocols described by Louzada et al. (2014) and Barfuss et al. (2016). Sequencing reactions were carried out with the same amplification primers using the sequencing service from Microsynth (Switzerland). Forward and reverse sequences were trimmed, edited and assembled using Geneious v.6.1.8 (Kearse et al., 2012). Consensus sequences were aligned using ClustalW implemented in Geneious v.6.1.8 and individual gap positions were treated as missing data. 


\section{LIBRARY PREPARATION AND GENOME SKIMMING SEQUENCING}

For library preparation, we quantified the DNA and diluted the samples in a $100 \mu \mathrm{l}$ solution containing $500 \mathrm{ng}$ of DNA and fragmented with a Bioruptor sonicator (Diagenode) to obtain fragments of 300700 bp. For samples with lower DNA content, we used $100 \mu \mathrm{l}$ of available aliquot without any dilution.

Library preparation was performed following de La Harpe et al. (2018). DNA clean-up, size selection, end-repair and the A-tailing steps were achieved with a KAPA LTP library preparation kit (Roche, Basel, Switzerland). Adaptor ligation and adaptor fill-in steps were based on Meyer \& Kircher (2010). For the majority of samples, an aliquot of $4 \mu \mathrm{l}$ of the ligated fragment solution was amplified for eight cycles using the KAPA HiFi DNA Polymerase (Roche, Basel, Switzerland) and the set of 60 dual-index primers designed by (Loiseau et al., 2019). Dual-indexed primers were chosen to avoid inaccuracies in multiplex sequencing (Kircher, Sawyer \& Meyer, 2012). Samples with a low amount of DNA were amplified for 12 cycles using $11 \mu \mathrm{l}$ of the ligated fragment solution. The products of library amplification were quantified using a Qubit Fluorometer v.2.2 (Thermo Fisher Scientific, Waltham, MA, USA). Genomic DNA libraries were pooled equimolarly and sequenced in an Illumina HiSeq 3000 Genome Analyzer (Illumina, San Diego, California, USA) in 1.5 lanes using $2 \times 150$ bp pairedend reads at the University of Bern.

\section{DNA QUALITY, ASSEMBLY AND ALIGNMENT}

Quality control, quality score per base, sequence duplication level and overrepresented sequences were checked with FASTQC (https://www.bioinformatics. babraham.ac.uk/projects/fastqc/). To remove sequencing errors, the reads were trimmed with CONDETRI v.2.2 (Smeds \& Künstner, 2011) using 20 as high-quality threshold parameter.

For each sample, all reads were mapped to the Tillandsia adpressiflora Mez pseudo-reference genome built in de La Harpe et al. (2018) using BOWTIE2 v.2.2.5 (Langmead \& Salzberg, 2012) and the '--verysensitive-local' option. This pseudo-reference genome was build using the high-quality and annotated Ananas comosus reference genome (Ming et al., 2015) as a start point. The method consisted of incorporating specific variation of T. adpressiflora into the Ananas genome to improve the mapping efficiency of samples of Tillandsioideae. This pseudo-reference contains the plastid genome.

To ensure the data quality, reads were realigned around indels, and the base quality of reads was re-calibrated using GATK v.3.6 (McKenna et al.,
2010). SNP calling was performed for the plastid genome using UnifiedGenotyper of GATK v.3.6 (McKenna et al., 2010) and the EMIT_ALL_SITES option to recover both variant and invariant sites. SNP calling was not performed for the nuclear genome as the sequencing depth of the genome skimming methods is not high enough to recover this genomic region. Only sites with a quality $\mathrm{Q}>20$, < $50 \%$ missing data and with a minimum depth of $3 \times$ were retained using vcftools v.0.1.13 (Danecek et al., 2011). Fasta files were generated using vcf-tabto-fasta (https://github.com/JinfengChen/vcf-tabto-fasta). Sequences were aligned using ClustalW implemented in Geneious 6.1.8 (Kearse et al., 2012). The samples that had $>50 \%$ missing data were removed from the alignment.

\section{SUBSAMPLING OF PLASTID GENES}

Most phylogenetic studies in Bromeliaceae are based on a few plastid genes and/or nuclear genes (Louzada et al., 2014; Evans et al., 2015; Aguirre-Santoro, Michelangeli \& Stevenson, 2016; Barfuss et al., 2016; Gomes-da-Silva \& Souza-Chies, 2017; Kessous et al., $2019)$, resulting in poor resolution in some genera. Increasing the molecular sampling effort would help in elucidating some of the hypotheses or resolving discordances (Kessous et al., 2019). Next-generation sequencing (NGS), and especially genome skimming that allows the sequencing of the whole plastid genome, represent great opportunities to overcome molecular data limitations in phylogenetic studies (Coissac et al., 2016). However, NGS methods have high cost and different challenges at the library preparation, sequencing and bioinformatics steps. For this reason, we tested if the use of a limited number of plastid genes would be sufficient to obtain high phylogenetic support within Vriesea. For this purpose, we performed the annotation of the partial plastome and selected the genes with a length $>900 \mathrm{bp}$ (similar to the length usually obtained using Sanger sequencing) from the genome skimming alignment. Annotation for the partial plastome alignment obtained for one species (Vriesea marceloi) was performed in Geneious v.6.1.8 (Kearse et al., 2012) using Tillandsia usneoides L. as a reference genome (NCBI number KY293680.1, Poczai \& Hyvönen, 2017). Then, a set of 18 high-quality genes with sequence length greater than 900 bp was selected and extracted from the annotated sequence. This selection included genes normally used in phylogenetic studies with Bromeliaceae and also described as variables in Poczai \& Hyvönen (2017).

To ensure that each region extracted from the annotated sequence of $V$. marceloi Versieux \& T.Machado corresponded to the selected genes, 
sequences were checked using nucleotide BLAST (Altschul et al., 1990) available at NCBI (https://www. ncbi.nlm.nih.gov/). After a quality check, each selected gene sequence was used as a reference to extract the corresponding region from the plastid alignment of all our samples. Then, the alignments extracted for each gene were checked again using nucleotide BLAST (Altschul et al., 1990), available at NCBI (https://www. ncbi.nlm.nih.gov/), to confirm the equivalence with the selected genes.

\section{PHYLOGENETIC ANALYSES}

We performed phylogenetic inference using three datasets: (1) a concatenated unpartitioned alignment of the plastome alignment generated by the genome skimming approach; (2) the nuclear gene phyC and (3) a concatenated alignment of 18 selected plastid genes and the nuclear phyC (18 plastid genes $+p h y C)$ to evaluate whether a reduced set of genes would have success in recovering well-supported trees. The latter was partitioned by genes and the best nucleotide substitution model for each gene was selected using JModelTest v.2.1.7 (Darriba et al., 2012) based on the Bayesian information criterion (BIC) (Table 1 ). The numbers of variable sites, conserved sites and potentially parsimony-informative sites were calculated in MEGA 7 (Kumar, Stecher \& Tamura, 2016) for all alignments (Table 1).

Maximum-likelihood (ML) analyses were performed using RAxML v.8.2.10 (Stamatakis, 2014) with 1000 rapid bootstrap replicate searches (Stamatakis, Hoover \& Rougemont, 2008). The partial plastome alignment, nuclear phyC and the concatenated 18 plastid genes $+p h y C$ were analysed using GTRGAMMA as a nucleotide substitution model.

Additionally, we applied a Bayesian inference (BI) approach to $p h y C$ and to the concatenated alignment of 18 plastid genes $+p h y C$, using MrBayes v.3.2.6 (Ronquist et al., 2012). As the size of the dataset (> 200 species and $>70000 \mathrm{bp}$ ) exceeds the computational limits of MrBayes, it was not possible to conclude the Bayesian analysis for the partial plastome. For each gene, we applied the best model of substitution selected by JModelTest (Table 1). Two independent runs of four Markov chains and 25 million generations were performed with sampling every 1000 generations. All phylogenetic analyses were performed on the CIPRES Science Gateway (Miller, Pfeiffer \& Schwartz, 2011). Convergence among the two runs was assessed in Tracer v.1.6.0 (Rambaut \& Drummond, 2003). The consensus phylogenetic tree and node posterior probabilities were computed from the posterior distribution of trees after removal of a burn-in of $25 \%$.

\section{RESULTS}

\section{GENOME SKIMMING}

The genome skimming approach generated 358443406 high-quality reads $(\mathrm{Q}>20$; including mitochondrial, nuclear and plastid reads) across the 206 samples successfully sequenced in this study. After mapping, SNP calling and quality filtering, an alignment of 77836 high-quality plastid bases was obtain for the 206 samples. Only $3.6 \%$ of missing data were observed in the alignment and $75654 \mathrm{bp}$ were obtained on average per sample. The final alignment (including gaps after adding outgroups) was $78483 \mathrm{bp}$ and contained 6212 variable characters of which 2849 were potentially parsimony-informative. To avoid ambiguity about our plastid genome data set, we will refer to it as 'partial plastome' from here on.

\section{SUBSAMPLING OF PLASTID GENES AND NUCLEAR PHYC GENE}

The partial plastome annotated of $V$. marceloi featured the four typical plastid regions: one large single copy (LSC 56433 bp), inverted repeat A (IRa 3197 bp), one small single copy (SSC $13259 \mathrm{bp}$ ) and inverted repeat B (IRb $4947 \mathrm{bp}$ ). The IRa and IRb were different sizes since the percentage of coverage and the recovered genes in each of these parts were not the same. Ninety genes were recovered for $V$. marceloi, 35 totally and 55 partially. Eighteen of these were selected and extracted from the partial plastome alignment and they are shown in Table 1.

The $p h y C$ alignment for the 171 samples was $1006 \mathrm{bp}$ long with 297 variable characters of which 159 were potentially parsimony-informative. The concatenated alignment of the 18 plastid genes $+p h y C$ had a total length of $31241 \mathrm{bp}, 2323$ of which were variable and 1205 potentially parsimony-informative (Table 1 ). For the calculation of conserved and variable sites, gaps were not considered. All sequences generated in this work were included in a free and online repository (NCBI, National Center for Biotechnology Information) number SUB6280204 for the raw read data and see Supporting Information, Table $\mathrm{S} 1$ for $p h y C$ sequences.

\section{PHYLOGENETIC RELATIONSHIPS}

The phylogenetic tree based on the partial plastome dataset (Fig. 2) had higher bootstrap support (BS) and recovered more clades than the one obtained from the $p h y C$ alone (Supporting Information, Fig. $\mathrm{S} 1$ ) and from 18 plastid genes + phyC (Supporting Information, Fig. S2). The main clades (tribes Tillandsieae and Vrieseeae, subtribes Cipuropsidinae and Vrieseinae) were recovered with high support on trees obtained from partial plastome and 18 plastid 
Table 1. Matrix allignment statistics. Recovery percentage is calculated in comparison with the genome used as reference for plastid annotation T. usneoides (Poczai \& Hyvönen, 2017). For the calculation of conserved and variable sites, gaps were not considered.

\begin{tabular}{|c|c|c|c|c|c|c|}
\hline & $\begin{array}{l}\text { Length of } \\
\text { alignment }\end{array}$ & $\begin{array}{l}\text { Recovery } \\
\%\end{array}$ & $\begin{array}{l}\text { Number of } \\
\text { conserved } \\
\text { sites }(\%)\end{array}$ & $\begin{array}{l}\text { Nunber of } \\
\text { variable } \\
\text { sites }(\%)\end{array}$ & $\begin{array}{l}\text { Number of potentially } \\
\text { parsimony-informative } \\
\text { sites }(\%)\end{array}$ & $\begin{array}{l}\text { Substitution } \\
\text { model }\end{array}$ \\
\hline$a t p A$ & 1527 & 100 & $1461(96)$ & $66(4)$ & $32(2)$ & $\mathrm{HKY}+\mathrm{I}$ \\
\hline$a t p B$ & 1086 & 75 & 1047 (96) & $39(4)$ & $16(1)$ & $\mathrm{HKY}+\mathrm{I}$ \\
\hline$a t p F$ & 1395 & 100 & $1286(92)$ & $109(8)$ & $54(4)$ & $\mathrm{F} 81+\mathrm{I}+\mathrm{G}$ \\
\hline $\operatorname{clp} P$ & 951 & 46 & 868 (91) & $80(8)$ & 37 (4) & $\mathrm{HKY}+\mathrm{I}$ \\
\hline$n d h A$ & 2060 & 96 & $1886(92)$ & $168(8)$ & $94(5)$ & HKY+I \\
\hline$n d h D$ & 1230 & 81 & $1142(93)$ & $73(6)$ & $32(3)$ & $\mathrm{HKY}+\mathrm{G}$ \\
\hline$p s a A$ & 1945 & 87 & $1889(97)$ & $56(3)$ & $23(1)$ & $\mathrm{HKY}+\mathrm{I}$ \\
\hline$p s a B$ & 1016 & 46 & $954(94)$ & $54(5)$ & $41(4)$ & $\mathrm{HKY}+\mathrm{I}+\mathrm{G}$ \\
\hline$p s b A$ & 1008 & 95 & $980(97)$ & $28(3)$ & $15(1)$ & $\mathrm{HKY}+\mathrm{I}$ \\
\hline$p s b B$ & 1246 & 81 & $1190(96)$ & $40(3)$ & $26(2)$ & $\mathrm{HKY}+\mathrm{I}$ \\
\hline rpl16 & 1221 & 82 & $1139(93)$ & $77(6)$ & $44(4)$ & $\mathrm{HKY}+\mathrm{I}+\mathrm{G}$ \\
\hline rpoB & 2153 & 67 & 2038 (95) & $105(5)$ & $58(3)$ & $\mathrm{GTR}+\mathrm{I}+\mathrm{G}$ \\
\hline rpoC1 & 2204 & 79 & $2053(93)$ & $134(6)$ & $75(3)$ & $\mathrm{HKY}+\mathrm{I}+\mathrm{G}$ \\
\hline rроC2 & 2172 & 55 & 2007 (92) & $165(8)$ & $74(3)$ & $\mathrm{HKY}+\mathrm{I}$ \\
\hline $\operatorname{trn} K$-UUU & 1838 & 68 & $1633(89)$ & 203 (11) & $100(5)$ & $\mathrm{GTR}+\mathrm{I}+\mathrm{G}$ \\
\hline trnl-GAU & 906 & 89 & 895 (99) & $11(1)$ & $2(0.2)$ & K80 \\
\hline$y c f 1$ & 4813 & 85 & $4171(87)$ & 563 (12) & $297(6)$ & $\mathrm{HKY}+\mathrm{I}+\mathrm{G}$ \\
\hline$y c f 3$ & 1464 & 73 & 1386 (95) & $67(5)$ & $30(2)$ & $\mathrm{HKY}+\mathrm{I}$ \\
\hline phyC & 1006 & - & $693(69)$ & $297(30)$ & $159(15)$ & $\mathrm{SYM}+\mathrm{I}+\mathrm{G}$ \\
\hline $\begin{array}{l}\text { All genes } \\
\text { concatenated }\end{array}$ & 31241 & - & $28730(92)$ & $2323(7)$ & $1205(4)$ & $\mathrm{GTR}+\mathrm{G}$ \\
\hline Partial plastome & 78483 & 49 & $71623(91)$ & $6212(8)$ & $2849(4)$ & $\mathrm{GTR}+\mathrm{G}$ \\
\hline
\end{tabular}

genes + phyC. However, the tree obtained from $p h y C$ recovered Cipuropsidinae as sister to Tillandsieae (BS 65/PP 0.95) and both as a sister group of Vrieseinae (BS 92/PP 0.89). The phyC tree recovered extremely low support values within Vriesea $(\mathrm{BS}<50$ and $\mathrm{PP}<0.50)$. For the tree obtained with 18 plastid genes + phyC, some clades were found in Vriesea, but in general, the groups received weak support (Supporting Information, Fig. S2). Therefore, only the results from the partial plastome are presented and discussed here (Fig. 2); the phylogenetic trees of the phyC and 18 plastid genes $+p h y C$ genes are shown in the Supporting Information (Figs S1, S2).

Tillandsieae were recovered with strong support (BS 100, Fig. 2) in a sister position to Vrieseeae, also strongly supported (BS 100, Fig. 2). Guzmania is monophyletic (BS 99) and sister to a clade composed of Tillandsia, Racinaea and Vriesea lutheriana J.R.Grant (BS 100, Fig. 2). Cipuropsidinae were strongly supported (BS 100, Fig. 2) and contained two clades also supported by a BS value of 100 . The first was formed by Werauhia (BS 99) and Lutheria (BS 100). The second was composed of Zizkaea, the non-monophyletic Goudaea and the lineages of the Cipuropsis-Mezobromelia complex (BS 100).
Vrieseinae, containing Alcantarea, Vriesea s.s. and Stigmatodon, were also recovered as monophyletic with strong support (BS 99, Fig. 2). Although Alcantarea was monophyletic with strong support (BS 100), Vriesea s.l. is polyphyletic. A group of species was nested in Stigmatodon (BS 100) and one species (V. lutheriana) clustered with Tillandsia. The separation between Vriesea and Stigmatodon was strongly supported with a BS value of 100 (Fig. 2). Vriesea drepanocarpa (Baker) Mez (Fig. 1G) was recovered as sister to all other species of Vriesea s.s. Within this group, 12 main clades were recovered with moderate-strong support in the partial plastome tree (BS values ranging from 80 to 100) (Fig. 2). Many Vriesea spp., including V. longicaulis (Baker) Mez, V. itatiaiae Wawra, V. medusa Versieux and V. ensiformis (Vell.) Beer, that were represented by more than two accessions were not recovered as monophyletic.

\section{DISCUSSION}

\section{GENOME SKIMMING EFFICIENCY AND PHYLOGENETIC UTILITY}

The genome skimming approach uses Illumina technology to obtain high-copy fractions of the genome 

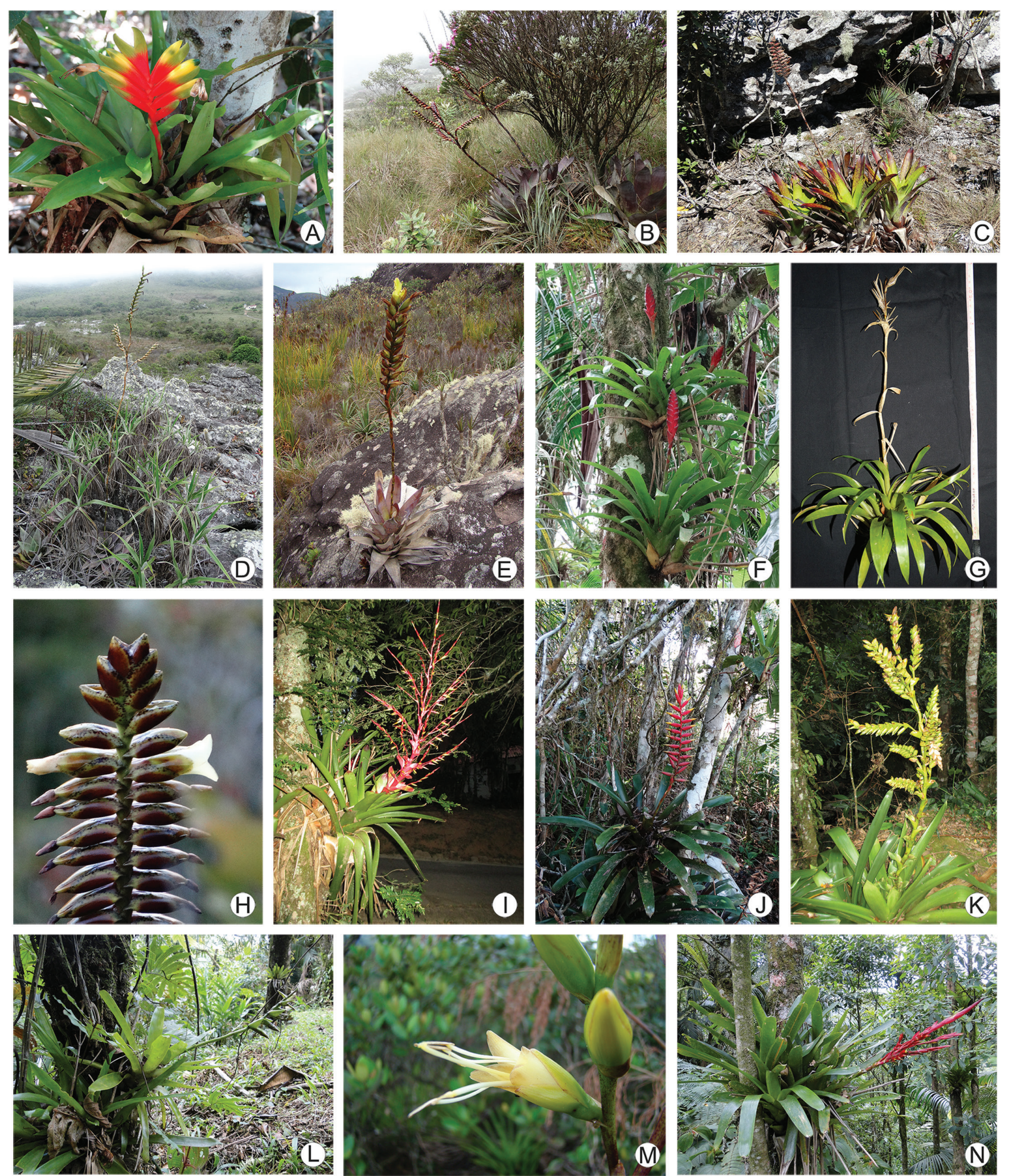

Figure 1. Species of the Vriesea s.s. clade showing habitat and inflorescence. A, Vriesea carinata. B, Vriesea medusa. C, Vriesea minor. D, Vriesea diamantinensis. E, Vriesea clausseniana. F, Vriesea gradata. G, Vriesea drepanocarpa. H, Vriesea pseudoatra. I, Vriesea philippocoburgii. J, Vriesea ensiformis. K, Vriesea hydrophora. L, Vriesea unilateralis. M, Vriesea longistaminea. N, Vriesea brusquensis. Photographs: T.M. Machado. 


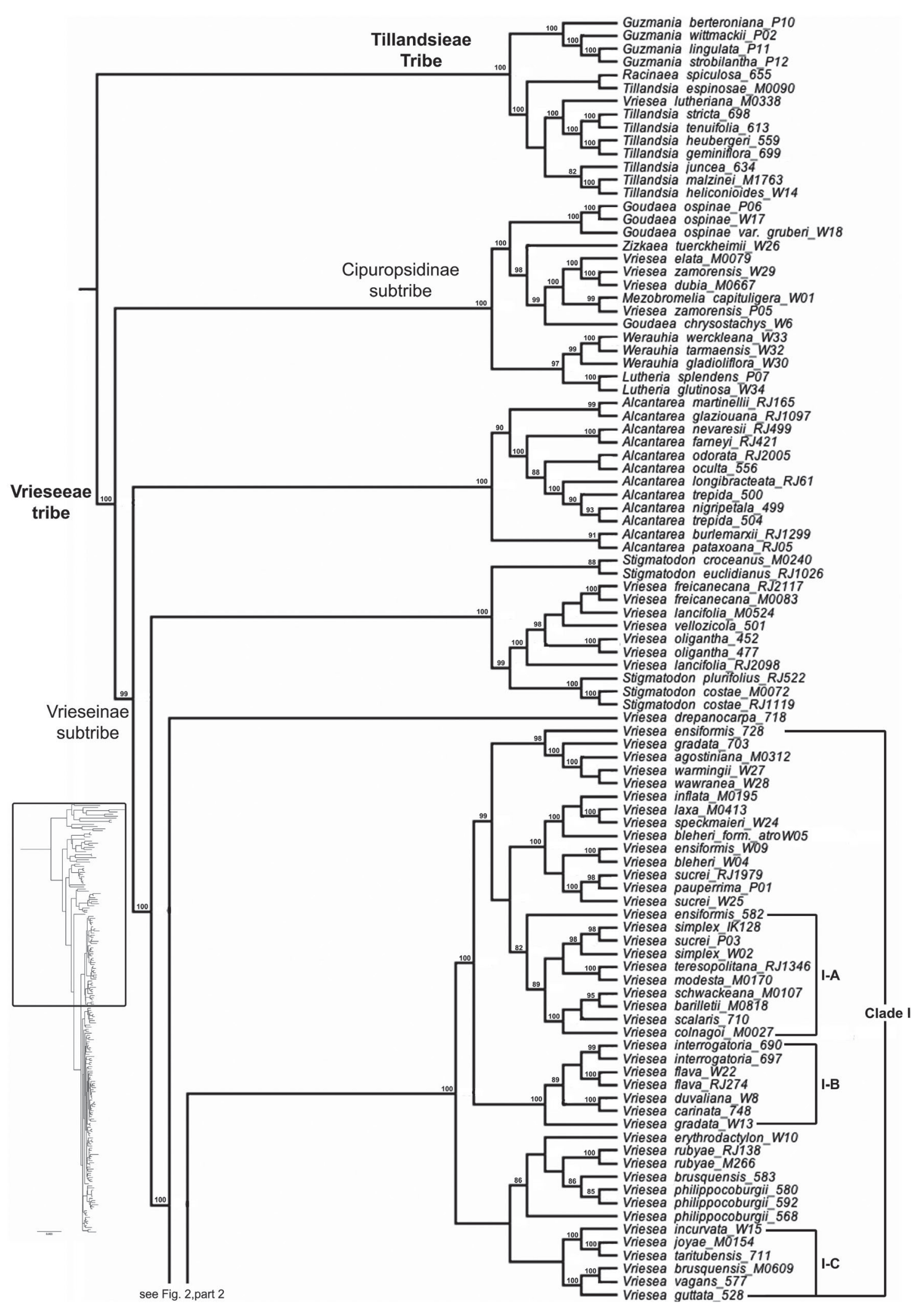




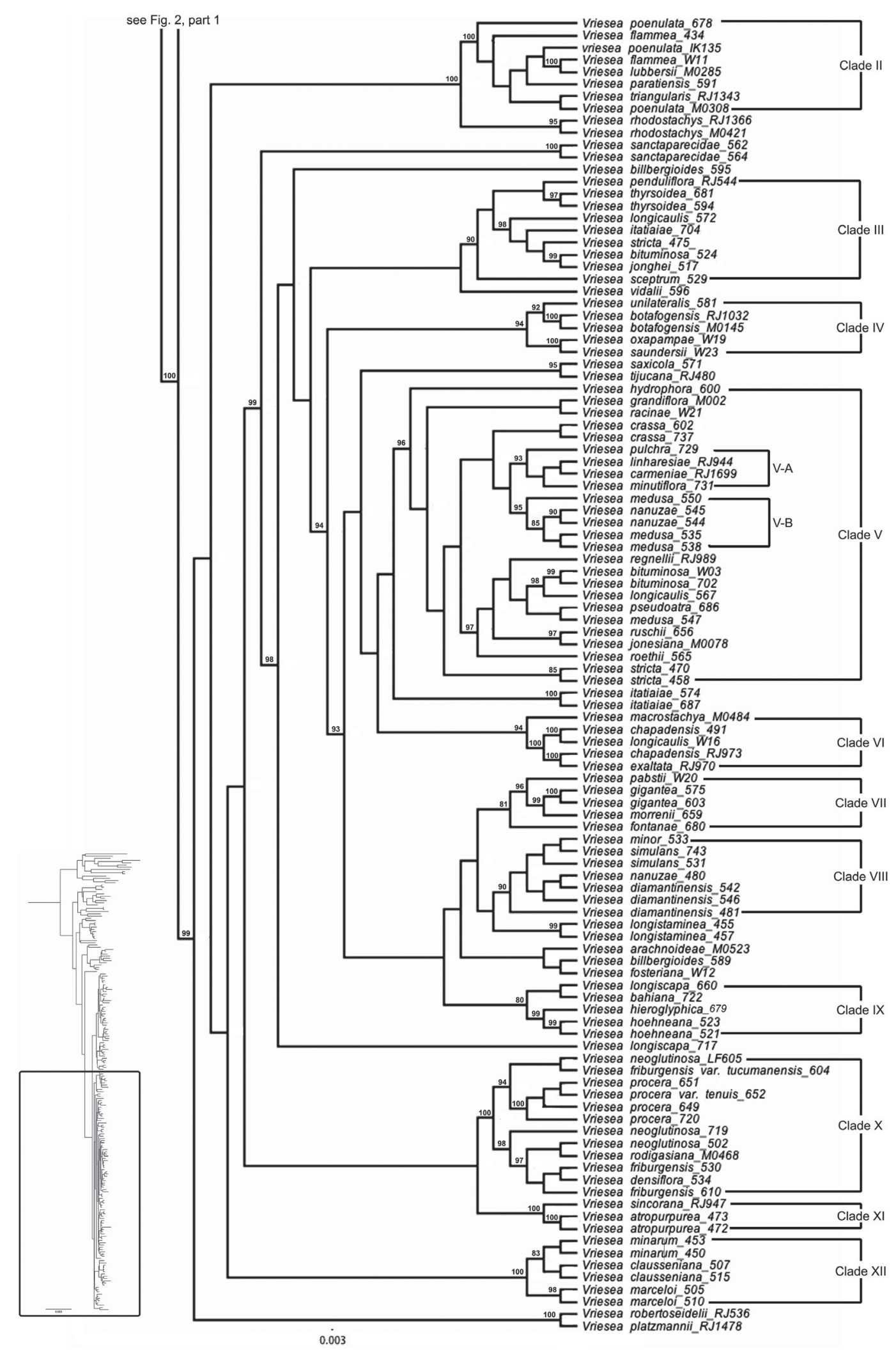


in low coverage, making it possible to retrieve sequence data for almost whole plastid genomes (Straub et al., 2012). When combined with a multiplex protocol (Meyer \& Kircher, 2010; Kircher et al., 2012), it allows multiple samples to be sequenced in a single run and thus to obtain a large amount of genomic data at an affordable cost (Straub et al., 2012; Malé et al., 2014; Dodsworth, 2015). Using this approach, we were able to recover nearly half of the plastid genome for 206 species of Tillandsioideae, to our knowledge representing an unprecedented genomic dataset for an evolutionary study in Bromeliaceae. The fact that we did not recover $>49 \%$ (an average of $75654 \mathrm{bp}$ ) of the plastid genome compared to the reference genome of the most closely related species, T. usneoides (159 $657 \mathrm{bp}$; Poczai \& Hyvönen, 2017) may be explained by the stringent quality filtering to retain a position in our study and by some extended deletions observed in our samples compared to the reference genome. Some authors suggest that a high level of multiplexing may reduce the sequencing capacity by up to 10-30\% (Straub et al., 2012). In our case, we obtain a high sequencing coverage for the plastid (36x on average per sample) and only $3.5 \%$ of missing data in our alignment of $77836 \mathrm{bp}$. The continuous advances in Illumina sequencing technologies now providing hundreds of millions of reads per lane and the option of using more than one Illumina lane of sequencing allowed us to obtain highquality data while multiplexing $>200$ samples.

Bromeliaceae show a low substitution rate (Smith \& Donoghue, 2008) and, in general, phylogenetic analyses produce trees with low resolution (Sass \& Specht, 2010; Maia et al., 2012; Versieux et al., 2012; Evans et al., 2015; Palma-Silva et al., 2016). Thus, phylogenetic studies of Bromeliaceae currently have sought more robust resolution by increasing the number of plastid markers and including nuclear markers (Krapp et al., 2014; Aguirre-Santoro et al. , 2016; Barfuss et al., 2016; PalmaSilva et al., 2016). The phyC is the most used nuclear gene in phylogenetic studies of Bromeliaceae (Silvestro et al., 2014; Louzada et al., 2014; Barfuss et al., 2016; Castello et al., 2016; Schütz et al., 2016; Goetze et al., 2017). In our dataset, $15 \%$ of all characters of $p h y C$ were potentially parsimony-informative, being the second most variable among the selected genes (Table 1). However, when analysed separately, it generated trees with strong support only for intergeneric relations, whereas within Vriesea support values were extremely low. A large polytomy and clades with low support were also found when analysing intrageneric relationships in Pitcairnioideae s.l. using $p h y C$, especially in relation to Puya and Dyckia Schult.f. (Jabaily \& Sytsma, 2010; Krapp et al., 2014; Schütz et al., 2016).

The concatenated matrix of 18 plastid genes $+p h y C$ resulted in trees with moderate support. Some of the major clades recovered by partial plastome were also recovered by this concatenated dataset, but the relationship between clades remained unclear due to lack of statistical support. Many of the selected genes were not fully recovered by genome skimming, but some showed a considerable number of potentially parsimony-informative and variable sites.

Comparing the results of the trees obtained with partial plastome data and the concatenated 18 plastid genes + phyC matrix, it is evident that the genome skimming approach is advantageous due to the large number of data obtained, in terms of both the number of base pairs and the number of species that can be multiplexed. In the case of our data, for which only partial plastomes were recovered, we were able to reconstruct phylogenetic trees that clarify intergeneric relationships with strong statistical support. However, for intrageneric relationships, the relationships between the recovered clades still lack statistical support. Other studies have shown that genome skimming may be effective in clarifying intrageneric relationships if few species are multiplexed, allowing a greater genome coverage (Parks, Cronn \& Liston, 2009; Kane et al., 2012; Malé et al., 2014; Dodsworth, 2015). In taxa that diverged recently, as is the case for most species of Bromeliaceae (Givnish et al., 2011, 2014), whole genome sequencing or target sequencing that produces hundreds of nuclear markers would be the next step to clarify intrageneric relationships.

\section{PHYLOGENETIC RELATIONSHIPS IN CORE TILLANDSIOIDEAE}

Petal appendages were a traditional morphological character used by Smith \& Downs (1977) to differentiate Tillandsia from Vriesea. However, ontogenetic sequences revealed that petal appendages are the last external multicellular structures formed during the development (Brown \& Terry, 1992). Several studies have demonstrated the fragility of this character to differentiate genera due to high levels of homoplasy (Schulte \& Zizka, 2008; Barfuss et al., 2016; Gomes-daSilva \& Souza-Chies, 2017). Nevertheless, the transfer

Figure 2. part 1. Cladogram from the ML analysis based on the partial plastome alignment (78 $483 \mathrm{bp}$ ) for 206 specimens of Tillandsioideae. Names of tribes, subtribes and genera follow the classification of Tillandsioideae proposed by Barfuss et al. (2016). Numbers above the branches represent ML and BS values. Only values > 50\% are shown. See Supporting Information for trees based on the nuclear gene $p h y C$ and the concatenation of 18 plastid genes + phyC. In detail: phylogram with proportional branch lengths from the ML tree. 
of Vriesea spp. with petal appendages to Tillandsia proposed by Grant (1993, 1995, 2004) was corroborated by the phylogenetic analyses of Barfuss et al. (2016) and Gomes-da-Silva \& Souza-Chies (2017). In our analysis, T. heliconioides Kunth, T. malzinei (E.Morren) Baker (formerly included in Vriesea) and T. juncea (Ruiz \& Pav.) Poir. represent Tillandsia subgenus Tillandsia. This group is sister to a well-supported clade composed of one species representative of the Tillandsia gardneri Lindl. complex, two species of Tillandsia subgens Anoplophytum (Beer) Baker and Vriesea lutheriana. The phylogenetic proximity of V. lutheriana with Tillandsieae highlights that, despite recent taxonomical rearrangements, Vriesea as currently circumscribed is still polyphyletic. Vriesea lutheriana was described by Grant (1992: 199) as a species from Costa Rica with tripinnate inflorescences and conduplicate-spiral stigma type. These morphological characteristics are closely related to that of $V$. duidae (L.B.Sm.) Gouda and V. rubrobracteata Rauh that have never been sequenced and V. elata (Baker) L.B.Sm. and V. zamorensis (L.B.Sm.) L.B.Sm. that were both recovered in the Cipuropsis-Mezobromelia complex sensu Barfuss et al. (2016). In addition to V. lutheriana, the tripinnate inflorescence type is also known from six Tillandsia spp. from Peru (León \& Alva, 2008). Two of these, T. hildae Rauh and T. ferreyrae L.B.Sm., were sampled in Barfuss et al. (2016) and formed a wellsupported clade with T. heliconioides and T. malzinei in Tillandsia subgenus Tillandsia. Likewise, the position of $V$. lutheriana with Tillandsia spp. revealed in our analyses is statistically supported, although we cannot establish the exact phylogenetic position due to our low sampling of Tillandsieae; we suggest further investigations of the relationships among the tripinnate species (V. lutheriana, T. hildae, T. ferreyrae).

In Cipuropsidinae, two well-supported main clades were identified. The first is composed of Werauhia and Lutheria. The second clade includes the species of Goudaea and Zizkaea, both newly described by Barfuss et al. (2016), and a clade called the CipuropsisMezobromelia complex by Barfuss et al. (2016) that is composed of the North-Andean species V. dubia (L.B.Sm.) L.B.Sm., V. zamorensis, V. elata and Mezobromelia capituligera (Griseb.) J.R.Grant. This group deserves further attention in order to clarify whether the type species of Cipuropsis (C. subandina Ule) will emerge among the mesomorphic northern Andean 'Vriesea' spp. and whether they are related to Mezobromelia (Barfuss et al., 2016; Gomes-da-Silva \& Souza-Chies, 2017). Finally, the two Goudaea spp. do not form a monophyletic group, as G. chrysostachys (E.Morren)W.Till \& Barfuss was found to be more closely related to the Cipuropsis-Mezobromelia complex than to G. ospinae (H.Luther) W.Till \&Barfuss. Therefore, our results do not support the circumscription of Barfuss et al. (2016) of Goudaea as a monophyletic genus.

In Vrieseinae, which comprise the eastern Brazilian lineages and were the focus of our taxonomic sampling, Alcantarea emerges as the sister group of Stigmatodon, a new genus segregated from Vriesea (Barfuss et al. 2016) and Vriesea s.s. Intrageneric phylogenetic relationships in Alcantarea were generally wellsupported (Fig. 2). Although our sampling of this genus is limited, evolutionary relationships seem to be linked to the geographical distribution since sister species tend to occur in geographical proximity [e.g. A. burlemarxii (Leme) J.R.Grant and A. pataxoana Versieux; A. glaziouana (Leme) J.R.Grant and A. martinellii Versieux \& Wand.], a pattern already highlighted by Versieux et al. (2012) for the species from the Serra dos Órgãos mountain range. Related species showing grouped geographical distribution pattern may be the result of forest fragmentation leading to geographical isolation of ancestral populations during the cycles of climatic changes of the Plio-Pleistocene and has been hypothesized as a putative driver of speciation in this genus (Benzing, 2000; Versieux et al., 2012). Our result indicates several Vriesea spp. [V. freicanecana J.A.Siqueira \& Leme, V. lancifolia (Baker) L.B.Sm., V. oligantha (Baker) Mez and V. vellozicola Leme \& J.A.Siqueira] cluster within the recently described genus Stigmatodon (Barfuss et al., 2016). These species, which are epiphytes on species of Vellozia Vand. or rupicolous plants on inselbergs and quartzite areas of the Espinhaço mountain range differ from the other members of the Stigmatodon clade in several morphological characters (e.g. stigma, rosette and floral/inflorescence structure) and habitat preferences. The taxonomic revision of Stigmatodon was performed by Couto (2017) who named the species of Vriesea nested in this genus the Vriesea limae L.B.Sm. group. Taxonomic rearrangements will be proposed for the re-circumscription of Stigmatodon as a monophyletic genus (D. Couto, personal communication).

Vriesea s.s. is considered to be the 'true' Vriesea because V. psittacina (Hook.) Lindl., the type species of the genus, is found in this lineage (Barfuss et al., 2016; Gomes-da-Silva \& Souza-Chies, 2017). According to Gomes-da-Silva \& Souza-Chies (2017), Vriesea s.s. contains species essentially distributed in the Paraná dominion (mostly Atlantic Forest) with a few occurrences in the Chacoan dominion. However, the increased taxonomic sampling of our analysis revealed that extra-Brazilian species such as V. laxa (Griseb.) Mez and V. speckmeieri W.Till from Venezuela, V. macrostachya (Bello) Mez from Puerto Rico and $V$. oxapampae Rauh from Peru, are also present in this clade, suggesting that calling this group of species the 'Brazilian lineage' is potentially misleading. Despite 
their geographical disjunction, these four species share a stigma convolute-blade type (Grant, 1997; Till, 2008), a character referred to by Gomes-da-Silva \& Souza-Chies (2017) as an important synapomorphy for the lineage. Thus, future research efforts in Vriesea should focus on the sampling of Vriesea spp. from the Amazon, the Guiana Shield and the Andes to investigate whether they belong to Vriesea s.s. or to the Cipuropsis-Mezobromelia complex.

In summary, in our study Vriesea spp. emerged in at least four evolutionary distinct lineages: (1) Tillandsia; (2) Cipuropsisinae; (3) Stigmatodon and (4) Vriesea s.s. Based on this result, further taxonomic rearrangements will be necessary to render Vriesea monophyletic.

\section{PHYLOGENETIC RELATIONSHIPS IN VRIESEA}

In Vriesea s.s., V. drepanocarpa (Baker) Mez was found in a sister position to the remaining species of the clade. This result contrasts with previous phylogenetic studies based on morphological and molecular data, in which this species was nested in Tillandsia, in a sister position to Racinaea (Gomes-da-Silva \& SouzaChies, 2017). Unlike the other species of Vriesea, which have six to 12 columns of ovules in the locule, $V$. drepanocarpa only has four columns, similar to some species of Tillandsia and Racinaea (Kuhn et al., 2016). Therefore, the close position of $V$. drepanocarpa to Tillandsia and Racinea in the study of Gomesda-Silva \& Souza-Chies (2017) might be explained by the fact that they included this morphological character in their phylogenetic analyses. In our ML phylogeny, a long branch separates $V$. drepanocarpa from the rest of the Vriesea s.s. clade. This suggests that the morphological differentiation of this species is underpinned by significant genetic divergence. Given that $V$. drepanocarpa also has a differentiated floral morphology with a simple-erect stigma type resembling that of Goudaea chrysostachys (Gomesda-Silva \& Souza-Chies, 2017), further studies are needed to confirm the exact phylogenetic position of this species.

Our study expands the sampling of Vriesea s.s. to species from other Brazilian biomes such as the Caatinga and the Cerrado, as well as to extraBrazilian species. Based on our plastid phylogenetic tree, we define 12 main clades that have a good statistical support within Vriesea s.s., and discuss their morphological or geographical characteristics.

Clade I includes 31 species (Fig. 2) combining nearly all sampled species with flat and simple inflorescences and tubular and distichous flowers, except for V. rhodostachys L.B.Sm. that was recovered as sister to clade II. Most of these species have complex morphological delimitations, often resulting in misapplied names in herbarium specimens (Costa et al., 2014). Some of these problematic species have been recently revised (Costa, Rodrigues \& Wanderley, 2009; Kessous, Salgueiro \& Costa, 2018; Neves et al., 2018). For instance, the V. paraibica Wawra complex was treated taxonomically by Costa et al. (2009) and is represented in our study by clade I-B comprising $V$. duvaliana E.Morren, $V$. carinata Wawra and V. gradata (Baker) Mez. However, the keels formed by two sepals, a synapomorphy for the group (Costa et al., 2015), are missing in the last species. Taxa in the $V$. incurvata Gaudich. complex, recently re-circumscribed (Neves et al., 2018), present simple inflorescences and suberect peduncles bearing bracts similar to the floral ones. In our phylogenetic tree, this group was recovered with high support in clade I-C, but it did not form a clade since $V$. sucrei L.B.Sm. \& Read was nested instead in clade I-A. The latter clade combines the largest number of species including the $V$. ensiformis complex treated by Kessous et al. (2018). Although clade I is composed mostly of species with simple inflorescences, it also includes four species with composed inflorescences and tubular flowers [V. vagans (L.B.Sm.) L.B.Sm., V. brusquensis Reitz, V. philippocoburgii Wawra and V. schwackeana Mez] and one species with simple inflorescences and campanulate corolla type (V. wawranea Antoine). Finally, with the exception of $V$. schwackeana, which occurs in the Cerrado domain, all species in this clade are mostly epiphytes (rarely terrestrial) distributed in the Atlantic Forest.

Clade II comprises the taxa from the $V$. corcovadensis Mez complex revised by Gomes-da-Silva \& Costa (2011) and Gomes-da-Silva et al. (2012), including V. poenulata (Baker) Mez, V. flammea L.B.Sm., V. lubbersii (Baker) E.Morren and V. triangularis Reitz. The monophyly of the group was already questioned in a cladistic analysis (Gomes-da-Silva et al., 2012), but further morphological and molecular analyses (Costa et al., 2015; Gomes-da-Silva \& Souza-Chies, 2017) confirmed that the V. corcovadensis complex is monophyletic. Our analysis confirms the previous result since $V$. arachnoidea A.F.Costa was found nested in a weakly supported clade related to clades VII and VIII. Although our sample of V. arachnoidea was labelled as a topotype in the living collection where we sampled it, we cannot exclude a misidentification to explain this unexpected placement in the phylogenetic analysis. In addition, $V$. paratiensis E.Pereira clustered in clade II even though it does not have stolons, utriculiform rosettes or linear-triangular blades that are considered as synapomorphies for this group.

Clade III includes eight species divided into two groups. The first one is composed of Vriesea penduliflora L.B.Sm. and V. thyrsoidea Mez, two epiphytic, terrestrial or rupicolous species that grow as at elevations $>1500 \mathrm{~m}$. Vriesea penduliflora is restricted 
to the higher areas of the Mantiqueira mountain range and is included in the Red List of the Brazilian Flora (CNCFlora, 2012a), whereas V. thyrsoidea is restricted to the higher parts of the Serra dos Orgãos. Both species have compound inflorescences, primary bracts covering the pedicel of the branches and tubular flowers secund at anthesis (Smith \& Downs, 1977). The second group includes V. longicaulis, V. itatiaiae, V. stricta L.B.Sm., V. bituminosa Wawra and $V$. jonghei (K.Koch) E.Morren. Several samples were included for each of these species and our result indicates that none of them are monophyletic. Vriesea sceptrum Mez emerged as sister of all other species in clade III and is a species restricted to the higher parts of the Mantiqueira mountain range. It is morphologically similar to $V$. penduliflora with compound inflorescences, primary bracts covering the pedicel of the branches but with tubular flowers never secund at anthesis (Machado \& Menini Neto, 2010).

Clade IV includes V. unilateralis (Baker) Mez, $V$. botafogensis Mez, V. oxapampae Rauh and V. saundersii (Carrière) E.Morren ex Mez. Vriesea saundersii and $V$. botafogensis were also recovered as member of a similar clade (i.e. clade R) in Gomes-daCosta \& Souza-Chies (2017). Vriesea botafogensis was considered as a synonym of $V$. saundersii until a decade ago because these species have similar inflorescences, flowers and rosettes and both are endemic to inselbergs in the city of Rio de Janeiro (Smith \& Downs, 1977; Leme \& Costa, 1994).

Clade V includes 17 species (Fig. 2) with simple or compound inflorescences and campanulate corolla type, with the exception of Vriesea stricta L.B.Sm. and $V$. jonesiana Leme that have tubular flowers. The floral morphology of most species in this clade was formerly used as a criteria to delimitate $V$. section Xiphion (E.Morren) E.Morren ex Mez, a group that has been shown to be non-natural (Versieux et al., 2012; Costa et al., 2015; Gomes-da-Silva \& SouzaChies, 2017). Two smaller groups stand out in clade V for their geographical structure. Clade V-A comprises $V$. pulchra Leme \& L.Kollmann, V. linharesiae Leme \& J.A.Siqueira, V. carmeniae R.Moura \& A.F.Costa and $V$. minutiflora Leme, all restricted to either the north-eastern region of Brazil or the Caatinga domain at elevations $>800 \mathrm{~m}$, except for $V$. pulchra that also occurs in the Atlantic Forest. Clade V-B includes the sympatric species $V$. medusa (Fig. 1B) and V. nanuzae Leme, restricted to montane areas in the Diamantina Plateau region along the central portion of the Espinhaço mountain range (Versieux, 2008; Versieux et al.,2010). These two species show great morphological similarity, both with compound and highly branched inflorescences as well as campanulate flowers secund at anthesis (Versieux, 2008; Leme, Trindade-Lima \& Ribeiro, 2010). These species are often misidentified in herbarium collections as $V$. diamantinensis Leme and V. simulans Leme (clade VIII) due to their similar morphologies. Furthermore, they also exhibit a great intraspecific morphological variation that renders their taxonomic delimitation challenging (pers. obs.) (Fig. 1B, D).

Clade VI includes species with simple inflorescences, distichous flowers and campanulate corolla type. Although they are morphologically closely related to clade $\mathrm{V}$, there is no support in our phylogenetic trees for a sister relationship among these two clades. Vriesea macrostachya (Bello) Mez, a species distributed in the Greater Antilles (Moura, 2011) was recovered as sister to all other species of the clade. Despite their disjunct distributions, V. macrostachya morphologically resembles $V$. chapadensis Leme, a species restricted to the rock outcrops in the northern part of the Espinhaço mountain range (Moura, 2011). One species in this clade ( $V$. longicaulis) has a distinct morphology with distichous floral bracts and flowers secund at anthesis. However, the three samples of this species are placed in distinct clades, making the position of this species uncertain.

Clades VII, VIII and IX are moderately supported clades containing 12 morphologically related species. The phylogenetic relationships among these three clades are weakly supported (Fig. 2). Most species present compound inflorescences with campanulate corolla type and flowers secund at anthesis. Although they share similarities regarding the inflorescence morphology, these clades are distributed in different habitats. Although the species of clade VII are epiphytes from the Atlantic Forest, species in Clade VIII a rupicolous species of the Cerrado domain and species of Clade IX are found at the transition between this biome and the Atlantic Forest (BFG, 2018).

Clade X includes six species: Vriesea neoglutinosa Mez, V. friburgensis Mez, V. procera (Mart. ex Schult. \& Schult.f.) Wittm., V. rodigasiana E.Morren and $V$. densiflora Mez. Vriesea densiflora has a tubular rosette and congest inflorescences with tubular yellow flowers. This species is rupicolous and is an endemic of rock outcrops in the Diamantina Plateau region along the central portion of the Espinhaço mountain range in the Cerrado domain (Versieux \& Wendt, 2006; Versieux et al., 2010). The placement of $V$. densiflora in clade $\mathrm{X}$, outside the ' $V$. minarum L.B.Sm. group', proposed by Versieux (2011), is surprising given its morphological and ecological divergence with the other species of this clade. All species except $V$. densiflora have infundibuliform rosettes, lax and compound inflorescences and usually reddish, yellow and tubular flowers with exserted stamens (except in $V$. procera in which they are included) (Smith \& Downs, 1977). They are epiphytic, rupicolous or terrestrial species distributed along the Atlantic Forest in several 
habitats of this domain as inselberg mats and restingas (BFG, 2018). Vriesea procera has a wide geographical distribution with species reaching northern South America, and is divided into four varieties (Smith \& Downs, 1977). Our data show that V. procera, $V$. neoglutinosa and $V$. friburgensis are related, and they have been recognized as the $V$. procera complex due to the difficulty in recognizing and delimiting taxa in this group (Versieux \& Wendt, 2006; Costa, Gomesda-Silva \& Wanderley, 2014; Uribbe, 2014).

Clade XI comprises V. sincorana Mez and $V$. atropurpurea Silveira, which share similarities in the rosette and inflorescences and have flowers with campanulate corollas and exserted stamens (Moura, 2011). Both species are restricted to the Espinhaço mountain range, but $V$. atropurpurea occurs to the south in the Cerrado domain, whereas $V$. sincoranea occurs to the north in the Caatinga domain (Moura, 2011; BFG, 2018). There is a striking phenotypic similarity between $V$. atropurpurea and $V$. longstaminea C.C.Paula \& Leme that leads to frequent misidentifications in herbaria (Leme \& Paula, 2004; Coffani-Nunes et al., 2010; Moura, 2011). They were recovered as sister species in the study of Gomes-da-Silva \& Souza-Chies (2017) and were treated as synonyms in Moura (2011). Vriesea longistaminea (Fig. $1 \mathrm{M}$ ) is restricted to an area of $<8$ $\mathrm{km}^{2}$ in an ironstone outcrop region known as the Iron Quadrangle (Leme \& Paula, 2004; Jacobi et al., 2007) and is categorized as Critically Endangered (CR) in the Red List of the Brazilian Flora (CNCFlora, 2012b). Vriesea atropurpurea and V. longistaminea do not occur sympatrically but their distributions are separated by only $100 \mathrm{~km}$. Despite their strong morphological similarity and geographic proximity, our analysis suggests that these species are not phylogenetically closely related since $V$. longistaminea is sister to clade VIII. Therefore, the morphological similarity between $V$. atropurpurea and V. longistaminea is probably a case of convergent adaptation to similar environmental conditions. In a large genus such as Vriesea, occupying contrasting environments including rock outcrops and ombrophilous forests, identifying occurrences of phenotypic convergence can help in elucidating the processes involved in the diversification of the group.

Clade XII includes Vriesea minarum L.B.Sm., $V$. clausseniana (Baker) Mez and V. marceloi Versieux \& T.M.Machado, all rupicolous and heliophytic species growing at $>1000 \mathrm{~m}$ elevation along the southern portion of the Espinhaço mountain range (Versieux et al., 2008). Specimens of V. marceloi can be found in herbaria identified as $V$. clausseniana and the two species occur sympatrically, although $V$. marceloi only grows above $1900 \mathrm{~m}$ of elevation where mist formation is frequent (Versieux \& Machado, 2012). Vriesea clausseniana has infundibuliform rosettes, and strongly secund yellow flowers at anthesis with campanulate corollas and exserted stamens. This floral morphology suggests a bat pollination, whereas $V$. minarum and $V$. marceloi have tubular rosettes and yellow tubular flowers secund at anthesis that are pollinated by hummingbird, suggesting that these floral characters are labile in this group (Versieux, 2011; Versieux \& Machado, 2012). These species were considered morphologically related to V. stricta (clades III and V) and $V$. densiflora (clade $\mathrm{X}$ ) in taxonomic works, but our genomic data placed them in different clades.

Many Vriesea spp. show considerable intraspecific morphological variation, and this is often insufficiently documented in morphological descriptions and poorly represented in identification keys (Costa et al., 2009; Neves et al., 2018). To address these complex species delimitations, we included more than one sample per species in our phylogenetic analysis. Our results show that many of these species are not monophyletic. For instance, two samples (547 and 550) of V. medusa collected in the same locality were found in distant positions in the phylogenetic tree. Likewise, the samples of $V$. itatiaiae (704 and 574) from the same locality did not appear as a monophyletic lineage. These findings could be explained either by the poor resolution between clades in Vriesea s.s. due to the lack of informative characters at a low level of divergence. Alternatively, the non-monophyly of many species of Vriesea could reflect true biological processes. Indeed, species complexes and non-monophyletic species are common in plants (Naciri \& Linder, 2015; Pinheiro, Dantas-Queiroz \& Palma-Silva, 2018) and are thought to be the result of hybridization or incomplete lineage sorting. Assuming that post-zygotic barriers for reproduction of bromeliads are potentially weak (Palma-Silva et al., 2011; Wagner et al., 2015) and that the individuals often grow in mixed aggregates of species sharing the same pollinator, interspecific gene flow may occur and lead to the formation of natural hybrids (Palma-Silva et al., 2011; Lexer et al., 2016; Zanella et al., 2016; Neri, Wendt \& Palma-Silva, 2017; Mota et al., 2019). Furthermore, natural hybrids of closely related Vriesea spp. have been identified (Zanella et al., 2016; Neri et al., 2017). Therefore, we hypothesize that hybridization could be one of the evolutionary process driving phenotypic variation and blurring species delimitation in the genus.

\section{CONCLUSIONS}

Our study provided the first phylogenetic hypothesis for Vrieseinae based on a comprehensive sampling of Vriesea and an extensive coverage of the plastid genome. The genome skimming approach used in this study allowed to recover large-scale plastid data to infer the evolutionary relationships in core Tillandsioideae with good support. Our results are congruent with 
the taxonomic rearrangements proposed by Barfuss et al. (2016), with the exception of Goudaea, which was not recovered as monophyletic. We show that Vriesea remains polyphyletic, as suggested in previous works, a finding that calls for further taxonomic rearrangements based in phylogenetic relationships and in-depth morphological studies. More specifically, this would include: the transference of V. lutheriana to Tillandsia; the transfer of several taxa to Stigmatodon; and a revision of Cipuropsis. Our analysis does not corroborate the delimitation of Vriesea s.s. proposed by Gomes-da-Silva \& Souza-Chies (2017), since we recovered Stigmatodon as a separate lineage, whereas it was nested in Vriesea s.s. in their study. Furthermore, we showed that Vriesea s.s. is not restricted to eastern Brazil; it also contains species distributed in the Andes, the Caribbean and in other southern South American countries. In Vriesea s.s., 12 strongly supported clades are recognized and supported by morphological characters or geography. Therefore, our phylogenetic study of Vriesea contributes to overcome some of the limitations of the traditional taxonomy based solely on morphological characters where well-defined morphological groups of species may include convergent, yet unrelated, taxa. Finally, our work provides the basis for the selection of Vriesea s.s. species to be used in future microevolutionary studies, which will aim at a better understanding of the drivers of the evolution of this important floristic component of the Brazilian Atlantic Forest.

\section{ACKNOWLEDGEMENTS}

The authors thank the Botanical Gardens of the University of Vienna (WU-HBV), Botanical Garden of Rio de Janeiro (RBvb), Marie Selby Botanical Garden (SEL) and Jardin des Serres d'Auteuil (P) for providing plant material and ICMBIO and IEF-MG for collection permits. TMM thanks all the amazing people who collaborated in the fieldwork and other stages of this work. TMM was supported by PhD fellowship grants of CAPES (Coordenação de Aperfeiçoamento de Pessoal de Nível Superior) and CNPq (Conselho Nacional de Desenvolvimento Científico e Tecnológico - CNPq-SWE (205660/2014-2)/CNPq (142354/2016-3)). LMV thanks CNPq (455510-2014-8 and 304778-2013-3). NS and CL received funding from the Swiss National Science Foundation (CRSII3-147630) and NS from the University of Lausanne.

\section{REFERENCES}

Aguirre-Santoro J, Michelangeli FA, Stevenson DW. 2016. Molecular phylogenetics of the Ronnbergia alliance (Bromeliaceae, Bromelioideae) and insights into their morphological evolution. Molecular Phylogenetics and Evolution 100: 1-20.
Almeida VR, da Costa AF, Mantovani A, GonçalvesEsteves V, de Oliveira Arruda R do C, Forzza RC. 2009. Morphological phylogenetics of Quesnelia (Bromeliaceae, Bromelioideae). Systematic Botany 34: 660-672.

Altschul SF, Gish W, Miller W, Myers EW, Lipman DJ. 1990. Basic local alignment search tool. Journal of Molecular Biology 215: 403-410.

Barfuss MHJ, Samuel R, Till W, Stuessy TF. 2005. Phylogenetic relationships in subfamily Tillandsioideae (Bromeliaceae) based on DNA sequence data from seven plastid regions. American Journal of Botany 92: 337-351.

Barfuss MHJ, Till W, Leme EM, Pinzón JP, Manzanares JM, Halbritter H, Samuel R, Brown GK. 2016. Taxonomic revision of Bromeliaceae subfam. Tillandsioideae based on a multi-locus DNA sequence phylogeny and morphology. Phytotaxa 279: 1-97.

Benzing DH. 2000. Bromeliaceae: profile of an adaptive radiation. New York: Cambridge University Press.

BFG- The Brazilian Flora Group. 2015. Growing knowledge: an overview of seed plant diversity in Brazil. Rodriguésia 66: 1085-1113.

BFG- The Brazilian Flora Group. 2018. Brazilian Flora 2020: innovation and collaboration to meet Target 1 of the Global Strategy for Plant Conservation (GSPC). Rodriguésia 69: 1513-1527.

Brown GK, Terry RG. 1992. Petal appendages in Bromeliaceae. American Journal of Botany 79: 1051-1071.

Castello LV, Barfuss MHJ, Till W, Galetto L, Chiapella JO. 2016. Disentangling the Tillandsia capillaris complex: phylogenetic relationships and taxon boundaries in Andean populations. Botanical Journal of the Linnean Society 181: 391-414.

CNCFlora. 2012a. Vriesea penduliflora. In: Lista Vermelha da flora brasileira versão 2012.2. Rio de Janeiro: Centro Nacional de Conservação da Flora. Available at: http:// cncflora.jbrj.gov.br/portal/pt-br/profile/Vriesea penduliflora. Accessed 1 April 2019.

CNCFlora. 2012b. Vriesea longistaminea. In: Lista Vermelha da Flora Brasileira versão 2012.2. Rio de Janeiro: Centro Nacional de Conservação da Flora. Available at: http://cncflora.jbrj.gov.br/portal/ pt-br/profile/Vriesea longistaminea. Accessed 10 March 2019.

Coffani-Nunes JV, Versieux LM, Wanderley M das GL, Pirani JR. 2010. Flora da Serra do Cipó, Minas Gerais, Brasil: Bromeliaceae-Tillandsioideae. Boletim de Botânica 28: $35-54$.

Coissac E, Hollingsworth PM, Lavergne S, Taberlet P. 2016. From barcodes to genomes: extending the concept of DNA barcoding. Molecular Ecology 25: 1423-1428.

Costa AF, Gomes-da-Silva J, Wanderley M das GL. 2014. Vriesea (Bromeliaceae, Tillandsioideae): taxonomic history, and morphology of the Brazilian lineage. The Journal of the Torrey Botanical Society 141: 338-353.

Costa AF da, Gomes-da-Silva J, Wanderley M das GL. 2015. Vriesea (Bromeliaceae, Tillandsioideae): a cladistic analysis of eastern Brazilian species based on morphological characters. Rodriguésia 66: 429-440. 
Costa AF da, Rodrigues PJFP, Wanderley M das GL. 2009. Morphometric analysis and taxonomic revision of the Vriesea paraibica complex (Bromeliaceae). Botanical Journal of the Linnean Society 159: 163-181.

Couto D. 2017. Revisão taxonômica e filogenia de Stigmatodon Leme, G.K. Br. \& Barfuss (Bromeliaceae - Tillandsioideae). Unpublished D. Phil. Thesis, Universidade Federal do Rio de Janeiro.

Crayn DM, Winter K, Smith JAC. 2004. Multiple origins of Crassulacean acid metabolism and the epiphytic habit in the Neotropical family Bromeliaceae. Proceedings of the National Academy of Sciences 101: 3703-3708.

Danecek P, Auton A, Abecasis G, Albers CA, Banks E, De Pristo MA, Handsaker RE, Lunter G, Marth GT, Sherry ST. 2011. The variant call format and VCFtools. Bioinformatics 27: 2156-2158.

Darriba D, Taboada GL, Doallo R, Posada D. 2012. jModelTest 2: more models, new heuristics and parallel computing. Nature Methods 9: 772.

Dodsworth S. 2015. Genome skimming for next-generation biodiversity analysis. Trends in Plant Science 20: 525-527.

Escobedo-Sarti J, Ramírez I, Leopardi C, Carnevali G, Magallón S, Duno R, Mondragon D. 2013. A phylogeny of Bromeliaceae (Poales, Monocotyledoneae) derived from an evaluation of nine supertree methods. Journal of Systematics and Evolution 51: 743-757.

Evans TM, Jabaily RS, de Faria APG, de Sousa L de OF, Wendt T, Brown GK. 2015. Phylogenetic relationships in Bromeliaceae subfamily Bromelioideae based on chloroplast DNA sequence data. Systematic Botany 40: 116-128.

Gilmartin AJ. 1973. Transandean distributions of Bromeliaceae in Ecuador. Ecology 54: 1389-1393.

Givnish TJ, Barfuss MHJ, Ee BV, Riina R, Schulte K, Horres R, Gonsiska PA, Jabaily RS, Crayn DM, Smith JAC, Winter K, Brown GK, Evans TM, Holst BK, Luther H, Till W, Zizka G, Berry PE, Sytsma KJ. 2011. Phylogeny, adaptive radiation, and historical biogeography in Bromeliaceae: insights from an eight-locus plastid phylogeny. American Journal of Botany 98: 872-895.

Givnish TJ, Barfuss MHJ, Ee BV, Riina R, Schulte K, Horres R, Gonsiska PA, Jabaily RS, Crayn DM, Smith JAC, Winter K, Brown GK, Evans TM, Holst BK, Luther H, Till W, Zizka G, Berry PE, Sytsma KJ. 2014. Adaptive radiation, correlated and contingent evolution, and net species diversification in Bromeliaceae. Molecular Phylogenetics and Evolution 71: 55-78.

Givnish TJ, Millam KC, Berry PE, Sytsma KJ. 2007. Phylogeny, adaptive radiation, and historical biogeography of Bromeliaceae inferred from $n d h F$ sequence data. Aliso: A Journal of Systematic and Evolutionary Botany 23: 3-26.

Goetze M, Zanella CM, Palma-Silva C, Büttow MV, Bered F. 2017. Incomplete lineage sorting and hybridization in the evolutionary history of closely related, endemic yellow-flowered Aechmea species of subgenus Ortgiesia (Bromeliaceae). American Journal of Botany 104: 1073-1087.

Gomes-da-Silva J, Costa AF da. 2011. A taxonomic revision of Vriesea corcovadensis group (Bromeliaceae: Tillandsioideae) with description of two new species. Systematic Botany 36: 291-309.

Gomes-da-Silva J, Souza-Chies TT. 2017. What actually is Vriesea? A total evidence approach in a polyphyletic genus of Tillandsioideae (Bromeliaceae, Poales). Cladistics 34:181-199.

Gomes-da-Silva J, Vargens FAC, Arruda RCO, Costa AF. 2012. A morphological cladistic analysis of the Vriesea corcovadensis group (Bromeliaceae: Tillandsiodeae), with anatomical descriptions: new evidence of the non-monophyly of the genus. Systematic Botany 37: 641-654.

Gouda EJ, Butcher D, Gouda CS. cont. updated. Encyclopaedia of bromeliads, version 4. Utrecht: University Botanic Gardens. http://bromeliad.nl/encyclopedia/. Accessed 20 February 2019.

Grant JR. 1992. Vriesea lutheriana, a new species with tripinnate inflorescence from Costa Rica. Journal of the Bromeliad Society (USA) 42:114-117.

Grant JR. 1993. True tillandsias misplaced in Vriesea (Bromeliaceae: Tillandsioideae). Phytologia 75: 170-175.

Grant JR. 1995. New combinations and new taxa in the Bromeliaceae. Phytologia 79: 254-256.

Grant JR. 1997. The identity of the West Indian endemic Vriesea macrostachya (Bromeliaceae). Nordic Journal of Botany 17: 157-159.

Grant JR. 2004. New combinations and names in Andean Pitcairnia, Tillandsia, and Werauhia. Vidalia 2: 23-25.

Heller S, Leme E, Schulte K, Benko-Iseppon AM, Zizka G. 2015. Elucidating phylogenetic relationships in the Aechmea alliance: AFLP analysis of Portea and the Gravisia complex (Bromeliaceae, Bromelioideae). Systematic Botany 40: $716-725$.

Horres R, Zizka G, Kahl G, Weising K. 2000. Molecular phylogenetics of Bromeliaceae: evidence from $\operatorname{trnL}(\mathrm{UAA})$ intron sequences of the chloroplast genome. Plant Biology 2: 306-315.

Jabaily RS, Sytsma KJ. 2010. Phylogenetics of Puya (Bromeliaceae): placement, major lineages, and evolution of Chilean species. American Journal of Botany 97: 337-356.

Jacobi CM, Do Carmo FF, Vincent RC, Stehmann JR. 2007. Plant communities on ironstone outcrops: a diverse and endangered Brazilian ecosystem. Biodiversity and Conservation 16: 2185-2200.

Kane N, Sveinsson S, Dempewolf H, Yang JY, Zhang D, Engels JMM, Cronk Q. 2012. Ultra-barcoding in cacao (Theobroma spp.; Malvaceae) using whole chloroplast genomes and nuclear ribosomal DNA. American Journal of Botany 99: 320-329.

Kearse M, Moir R, Wilson A, Stones-Havas S, Cheung M, Sturrock S, Buxton S, Cooper A, Markowitz S, Duran C. 2012. Geneious Basic: an integrated and extendable desktop software platform for the organization and analysis of sequence data. Bioinformatics 28: 1647-1649.

Kessous IM, Neves B, Couto DR, Paixão-Souza B, Pederneiras LC, Moura RL, Barfuss MH, Salgueiro F, Costa AF. 2019. Historical biogeography of a Brazilian lineage of Tillandsioideae (subtribe Vrieseinae, Bromeliaceae): the Paranaean Sea hypothesized as the main 
vicariant event. Botanical Journal of the Linnean Society 192: 625-641.

Kessous IM, Salgueiro F, Costa AF. 2018. Nomenclature and epitypification of Vriesea (Bromeliaceae) species described in Vellozo's Flora fluminensis. Phytotaxa 350: 24-32.

Kircher M, Sawyer S, Meyer M. 2012. Double indexing overcomes inaccuracies in multiplex sequencing on the Illumina platform. Nucleic Acids Research 40: e3.

Krapp F, Pinangé DS de B, Benko-Iseppon AM, Leme EMC, Weising K. 2014. Phylogeny and evolution of Dyckia (Bromeliaceae) inferred from chloroplast and nuclear sequences. Plant Systematics and Evolution 300: 1591-1614.

Krömer T, Kessler M, Herzog SK. 2006. Distribution and flowering ecology of bromeliads along two climatically contrasting elevational transects in the Bolivian Andes. Biotropica 38: 183-195.

Kuhn SA, Nogueira FM, Fagundes NF, Mariath JE. 2016. Morphoanatomy of the ovary and ovule in Bromeliaceae subfamily Tillandsioideae and its systematic relevance. Botanical Journal of the Linnean Society 181: 343-361.

Kumar S, Stecher G, Tamura K. 2016. MEGA7: molecular evolutionary genetics analysis version 7.0 for bigger datasets. Molecular Biology and Evolution 33: 1870-1874.

de La Harpe M, Hess J, Loiseau O, Salamin N, Lexer C, Paris M. 2018. A dedicated target capture approach reveals variable genetic markers across micro- and macroevolutionary time scales in palms. Molecular Ecology Resources 19: 221-234.

de La Harpe M, Paris M, Hess J, Barfuss MH, SerranoSerrano ML, Ghatak A, Chaturvedi P, Weckwerth W, Till W, Salamin N. 2018. Genomic footprints of repeated evolution of CAM photosynthesis in tillandsioid bromeliads. bioRxiv 495812.

Langmead B, Salzberg SL. 2012. Fast gapped-read alignment with Bowtie 2. Nature Methods 9: 357-359.

Leme EM, Heller S, Zizka G, Halbritter H. 2017. New circumscription of Cryptanthus and new cryptanthoid genera and subgenera (Bromeliaceae: Bromelioideae) based on neglected morphological traits and molecular phylogeny. Phytotaxa 318: 1-88.

Leme EM, Paula CC. 2004. Two new species of Brazilian Bromeliaceae. Vidalia 2: 21-29.

Leme EM, Trindade-Lima T, Ribeiro OB de C. 2010. Revision of the lithophytic Vriesea species from Minas Gerais State, Brazil-Part IV. Journal of the Bromeliad Society 60: $17-31$.

Leme EMC, Costa A. 1994. Vriesea saundersii e V. botafogensis duas espécies distintas. Bromélia 1: 11-18.

León B, Alva AS. 2008. General overview of Tillandsia subgenus Tillandsia in Peru: the three-pinnate species and the case of two endemic species. Revista Peruana de Biología 15: $25-30$.

Lexer C, Marthaler F, Humbert S, Barbará T, de la Harpe M, Bossolini E, Paris M, Martinelli G, Versieux LM. 2016. Gene flow and diversification in a species complex of Alcantarea inselberg bromeliads. Botanical Journal of the Linnean Society 181: 505-520.
Loiseau O, Olivares I, Paris M, de La Harpe M, Weigand A, Koubinova D, Rolland J, Bacon CD, Balslev H, Borchsenius F, Cano A, Couvreur TLP, Delnatte C, Fardin F, Gayot M, Mejia F, Machado TM, Perret M, Roncal J, Sanin MJ, Stauffer F, Lexer C, Kessler M, Salamin N. 2019. Targeted capture of hundreds of nuclear genes unravels phylogenetic relationships of the diverse Neotropical palm tribe Geonomateae. Frontiers in Plant Science 10: 864.

Louzada RB, Schulte K, Wanderley M das GL, Silvestro D, Zizka G, Barfuss MHJ, Palma-Silva C. 2014. Molecular phylogeny of the Brazilian endemic genus Orthophytum (Bromelioideae, Bromeliaceae) and its implications on morphological character evolution. Molecular Phylogenetics and Evolution 77: 54-64.

Machado TM, Forzza RC, Stehmann JR. 2016. Bromeliaceae from Caparaó National Park, Minas Gerais/Espírito Santo states, Brazil, with notes on distribution and conservation. Oecologia Australis 20:133-146.

Machado TM, Menini Neto L. 2010. Bromeliaceae de um campo de altitude no sul de Minas Gerais (Brasil). Fontqueria 56: $109-124$.

Maciel JR, Louzada RB, Benko-Iseppon AM, Zizka G, Alves M. 2018. Polyphyly and morphological convergence in Atlantic Forest species of Aechmea subgenus Chevaliera (Bromeliaceae). Botanical Journal of the Linnean Society 188: $281-295$.

Maia VH, Da Mata CS, Franco LO, Cardoso MA, Cardoso SRS, Hemerly AS, Ferreira PCG. 2012. DNA barcoding Bromeliaceae: achievements and pitfalls. PLoS One 7: e29877.

Malé PJG, Bardon L, Besnard G, Coissac E, Delsuc F, Engel J, Lhuillier E, Scotti-Saintagne C, Tinaut A, Chave J. 2014. Genome skimming by shotgun sequencing helps resolve the phylogeny of a pantropical tree family. Molecular Ecology Resources 14: 966-975.

Martinelli G, Valente ASM, Maurenza D, Kutschenko DC, Judice DM, Silva DS, Fernandez EP, Martins EM, Barros FSM, Sfair JC. 2013. Avaliações de risco de extinção de espécies da flora brasileira. In: Martinelli G, Moraes MA, eds. Livro vermelho da Flora do Brasil. Rio de Janeiro: Andrea Jacobsson Estúdio, Instituto de Pesquisas Jardim Botânico, 60-84.

Martinelli G, Vieira CM, Gonzalez M, Leitman P, Piratininga A, da Costa AF, Forzza RC. 2008. Bromeliaceae da Mata Atlântica brasileira: lista de espécies, distribuição e conservação. Rodriguésia 59: 209-258.

Matuszak-Renger S, Paule J, Heller S, Leme EM, Steinbeisser GM, Barfuss MH, Zizka G. 2018. Phylogenetic relationships among Ananas and related taxa (Bromelioideae, Bromeliaceae) based on nuclear, plastid and AFLP data. Plant Systematics and Eevolution 304: 841-851.

McKenna A, Hanna M, Banks E, Sivachenko A, Cibulskis K, Kernytsky A, Garimella K, Altshuler D, Gabriel S, Daly M. 2010. The genome analysis toolkit: a MapReduce framework for analyzing next-generation DNA sequencing data. Genome Research 20: 1297-1303. 
Meyer M, Kircher M. 2010. Illumina sequencing library preparation for highly multiplexed target capture and sequencing. Cold Spring Harbor Protocols 2010: prot5448pdb.prot5448.

Miller MA, Pfeiffer W, Schwartz T. 2011. The CIPRES science gateway: a community resource for phylogenetic analyses. In: Proceedings of the 2011 TeraGrid Conference: Extreme Digital Discovery. Salt Lake City: ACM.

Ming R, VanBuren R, Wai CM, Tang H, Schatz MC, Bowers JE, Lyons E, Wang ML, Chen J, Biggers E, Zhang J, Huang L, Zhang L, Miao W, Zhang J, Ye Z, Miao C, Lin Z, Wang H, Zhou H, Yim WC, Priest HD, Zheng C, Woodhouse M, Edger PP, Guyot R, Guo HB, Guo H, Zheng G, Singh R, Sharma A, Min X, Zheng Y, Lee H, Gurtowski J, Sedlazeck J, Harkess A, McKain MR, Liao Z, Fang J, Liu J, Zhang X, Zhang Q, Hu W, Qin Y, Wang K, Chen LY, Shirley N, Lin YR, Liu LY, Hernandez AG, Wright CL, Bulone V, Tuskan GA, Heath K, Zee F, Moore PH, Sunkar R, Leebens-Mack JH, Mockler T, Bennetzen JL, Freeling M, Sankoff D, Paterson AH, Zhu X, Yang X, Smith JAC, Cushman JC, Paull RE, Yu Q. 2015. The pineapple genome and the evolution of CAM photosynthesis. Nature Genetics 47: 1435.

Mota MR, Pinheiro F, Leal BSS, Wendt T, Palma-Silva C. 2019. The role of hybridization and introgression in maintaining species integrity and cohesion in naturally isolated inselberg bromeliad populations. Plant Biology 21: 122-132.

Moura RL. 2011. Revisão taxonômica do grupo Vriesea platynema Gaudich. (Bromeliaceae). Unpublished D. Phil. Thesis, Universidade Federal do Rio de Janeiro.

Naciri Y, Linder HP. 2015. Species delimitation and relationships: the dance of the seven veils. Taxon 64: 3-16.

Neri J, Wendt T, Palma-Silva C. 2017. Natural hybridization and genetic and morphological variation between two epiphytic bromeliads. AoB Plants 10: plx061.

Neves B, Uribbe FP, Jacques SSA, Zanella CM, da Costa AF. 2018. Species boundaries in the Vriesea incurvata (Bromeliaceae) complex after a broad morphometric and taxonomic study. Systematic Botany 43: 870-888.

Palma-Silva C, Leal BSS, Chaves CJN, Fay MF. 2016. Advances in and perspectives on evolution in Bromeliaceae. Botanical Journal of the Linnean Society 181: 305-322.

Palma-Silva C, Wendt T, Pinheiro F, Barbará T, Fay MF, Cozzolino S, Lexer C. 2011. Sympatric bromeliad species (Pitcairnia spp.) facilitate tests of mechanisms involved in species cohesion and reproductive isolation in Neotropical inselbergs. Molecular Ecology 20: 3185-3201.

Parks M, Cronn R, Liston A. 2009. Increasing phylogenetic resolution at low taxonomic levels using massively parallel sequencing of chloroplast genomes. BMC Biology 7: 1 .

Pinangé DS, Krapp F, Zizka G, Silvestro D, Leme EM, Weising K, Benko-Iseppon AM. 2016. Molecular phylogenetics, historical biogeography and character evolution in Dyckia (Bromeliaceae, Pitcairnioideae). Botanical Journal of the Linnean Society 183: 39-56.

Pinheiro F, Dantas-Queiroz MV, Palma-Silva C. 2018. Plant species complexes as models to understand speciation and evolution: a review of South American studies. Critical Reviews in Plant Sciences 37: 54-80.

Poczai P, Hyvönen J. 2017. The complete chloroplast genome sequence of the CAM epiphyte Spanish moss (Tillandsia usneoides, Bromeliaceae) and its comparative analysis. PLoS One 12: e0187199.

Rambaut A, Drummond AJ. 2003. Tracer: MCMC trace analysis tool. Available at: http://tree.bio.ed.ac.uk/software/ tracer/5.

Ronquist F, Teslenko M, Van Der Mark P, Ayres DL, Darling A, Höhna S, Larget B, Liu L, Suchard MA, Huelsenbeck JP. 2012. MrBayes 3.2: efficient Bayesian phylogenetic inference and model choice across a large model space. Systematic Biology 61: 539-542.

Sass C, Specht CD. 2010. Phylogenetic estimation of the core bromelioids with an emphasis on the genus Aechmea (Bromeliaceae). Molecular Phylogenetics and Evolution 55: $559-571$.

Schulte K, Zizka G. 2008. Multi locus plastid phylogeny of Bromelioideae (Bromeliaceae) and the taxonomic utility of petal appendages and pollen characters. Candollea 63: 209-225.

Schütz N, Krapp F, Wagner N, Weising K. 2016. Phylogenetics of Pitcairnioideae s.s. (Bromeliaceae): evidence from nuclear and plastid DNA sequence data. Botanical Journal of the Linnean Society 181: 323-342.

Silvestro D, Zizka G, Schulte K. 2014. Disentangling the effects of key innovations on the diversification of Bromelioideae (Bromeliaceae). Evolution 68: 163-175.

Smeds L, Künstner A. 2011. ConDeTri-a content dependent read trimmer for Illumina data. PLoS One 6: e26314.

Smith LB, Downs RJ. 1974. Pitcairnioideae (Bromeliaceae). Flora Neotropica Monographs 14: 1-662.

Smith LB, Downs RJ. 1977. Tillandsioideae (Bromeliaceae). Flora Neotropica Monographs 14: 663-1492.

Smith SA, Donoghue MJ. 2008. Rates of molecular evolution are linked to life history in flowering plants. Science 322: $86-89$.

Stamatakis A. 2014. RAxML version 8: a tool for phylogenetic analysis and post-analysis of large phylogenies. Bioinformatics 30: 1312-1313.

Stamatakis A, Hoover P, Rougemont J. 2008. A rapid bootstrap algorithm for the RAxML web servers. Systematic Biology 57: 758-771.

Straub SC, Parks M, Weitemier K, Fishbein M, Cronn RC, Liston A. 2012. Navigating the tip of the genomic iceberg: next-generation sequencing for plant systematics. American Journal of Botany 99: 349-364.

Terry RG, Brown GK, Olmstead RG. 1997a. Phylogenetic relationships in subfamily Tillandsioideae (Bromeliaceae) using $n d h F$ sequences. Systematic Botany 22: 333-345.

Terry RG, Brown GK, Olmstead RG. 1997b. Examination of subfamilial phylogeny in Bromeliaceae using comparative sequencing of the plastid locus ndhF. American Journal of Botany 84: 664-664.

Till W. 2008. Vriesea speckmaieri-a new lower-altitude cloud forest species from northern Venezuela. Journal of the Bromeliad Society 58: 250-255. 
Uribbe FP. 2014. Variação morfológica no complexo Vriesea procera (Mart. ex Schult. \& Schult. f. (Tillandsioideae, Bromeliaceae). Unpublished Master's Thesis, Universidade Federal do Rio de Janeiro.

Versieux LM. 2008. Checklist and one new species of Bromeliaceae from Pico do Itambé, Minas Gerais, Brazil. Botanical Journal of the Linnean Society 158: 709-715.

Versieux LM. 2011. Brazilian plants urgently needing conservation: the case of Vriesea minarum (Bromeliaceae). Phytotaxa 28: 35-49.

Versieux LM, Barbará T, Wanderley M das GL, Calvente A, Fay MF, Lexer C. 2012. Molecular phylogenetics of the Brazilian giant bromeliads (Alcantarea, Bromeliaceae): implications for morphological evolution and biogeography. Molecular Phylogenetics and Evolution 64: 177-189.

Versieux LM, Louzada RB, Viana PL, Mota N, Wanderley MGL. 2010. An illustrated checklist of Bromeliaceae from Parque Estadual do Rio Preto, Minas Gerais, Brazil, with notes on phytogeography and one new species of Cryptanthus. Phytotaxa 10: 1-16.
Versieux LM, Machado TM. 2012. A new ornithophilous yellow-flowered Vriesea (Bromeliaceae) from Serra do Caraça, Minas Gerais, Brazil. Phytotaxa 71: 36-41.

Versieux LM, Wendt T. 2006. Checklist of Bromeliaceae of Minas Gerais, Brazil, with notes on taxonomy and endemism. Selbyana 27: 107-146.

Versieux LM, Wendt T. 2007. Bromeliaceae diversity and conservation in Minas Gerais state, Brazil. Biodiversity and Conservation 16: 2989-3009.

Versieux LM, Wendt T, Louzada RB, Wanderley MGL. 2008. Bromeliaceae da Cadeia do Espinhaço. Megadiversidade 4: 98-110.

Wagner ND, Wöhrmann T, Öder V, Burmeister A, Weising K. 2015. Reproduction biology and chloroplast inheritance in Bromeliaceae: a case study in Fosterella (Pitcairnioideae). Plant Systematics and Evolution 301: 2231-2246.

Zanella CM, Palma-Silva C, Goetze M, Bered F. 2016. Hybridization between two sister species of Bromeliaceae: Vriesea carinata and V. incurvata. Botanical Journal of the Linnean Society 181: 491-504.

\section{SUPPORTING INFORMATION}

Additional Supporting Information may be found in the online version of this article at the publisher's web-site:

Figure S1. Cladogram from the maximum-likelihood (ML) analysis based on nuclear gene $p h y C$ for 171 specimens of Tillandsioideae. First numbers above the branches represent bootstrap values (BS) and the second number represents posterior probabilities (PP). Only values $>50 \%$ are shown. In detail, phylogram with proportional branch lengths from the BI and ML analyses.

Figure S2. Cladogram from the Bayesian inference (BI) based on 19 concatenated genes (atpA, atpB, atpF, clpP, $n d h A, n d h D, p s a A, p s a B, p s b A, p s b B, r p l 16, r p o B, r p o C 1, r p o C 2, \operatorname{trnK}-U U U, \operatorname{trnl}-G A U, y c f 1, y c f 3, p h y C)$ for 206 species of Tillandsioideae. The first number above the branches represents PP, and the second number represents BS values. Only values $>50 \%$ are shown. In detail, phylogram with proportional branch lengths from the BI and ML analyses.

Table S1. Studied material with silica number/NCBI sample names for plastid reads (SUB6280204), voucher, locality and GenBank accession numbers for nuclear gene phyC. Abbreviations: BHCB, Herbarium of Universidade Federal de Minas Gerais; R, Herbarium of Museu Nacional (Brazil); RBvb, Bromeliad Living Collection of the Botanical Garden of Rio de Janeiro; SEL, Marie Selby Botanical Garden; WU-HBV, Botanical Garden of the University of Vienna; P, Jardin des Serres d'Auteuil Botanical Garden. 